\title{
Indigenous Knowledge System (IKS) and Sustainable Development in Nigeria: The Candidature of Language of Immediate Community (LIC)
}

\author{
Acheoah, John Emike*, Abdullah Sanni ${ }^{1}$, Olaleye Joel Iyiola ${ }^{2}$, Monday Eje ${ }^{3}$ \\ *Department of European Languages, Federal University, Birnin-Kebbi, Nigeria \\ ${ }^{1}$ Department of European Languages, Federal University, Birnin-Kebbi, Nigeria. \\ ${ }^{2}$ Waziri Umar Federal Polytechnic, Birnin-Kebbi, Nigeria. \\ ${ }^{3}$ Department of Languages and Linguistics, Federal University, Dutsin-ma, Nigeria. \\ *actualemike@gmail.com
}

\begin{abstract}
In Nigeria, English is still the medium of instruction in schools. "Development" is a concept that scholars view in different perspectives. It involves both "change" and "growth". Although "change" can either be positive or negative, this paper focuses on the positive sense of the term, and therefore depicts development as growth. The paper hinges on U. Thant's Theory of Development, and argues for the candidature of Language of Immediate Community (LIC), not as a sole medium of instruction in schools, but as a Nigerian language that should be taught alongside English in communities which host such schools. However, there should be public examination of selected languages of immediate communities. Part of the findings of this study is that literacy in LIC fosters national cohesion, social mobilization and sustainable development.
\end{abstract}

Keywords: National development, English studies, Language of Immediate Community (LIC), Public Examination of Selected Language of Immediate Community (PESLIC)

\section{INTRODUCTION}

Within the context of this paper, sustainable development is multi-dimensional growth, lingering progress within a given society. It presupposes improved standard of living. This paper investigates the place of language in Indigenous Language System (IKS) within the context of Nigeria's development. Indeed, Indigenous Knowledge System has political, social, economic, technological, administrative, religious, and a host of other functions in society. The system operates in all languages and cultures without compulsorily having specific theories for specific languages. Over time, perspectives on indigenous knowledge within linguistic purview have been dynamic and diverse. Indigenous knowledge elements may change over time, but those of the present share similarities with past ones since the latter are essentially goal-driven improvements on predating ones, as societies confront the challenges of globalization in medicine, science and technology, politics, etc.

Mastery of discrete skills in English, Nigeria's lingua franca, is for the overall development of the country. Thus, it is logical to submit that indigenous Nigerian languages have roles to play in national cohesion, invention and mobilization. Scholars view development from different perspectives, being that the definition is not exhaustive; it is intractable. According to U. Thant cited by Gheddo (1973:1) "Development is imperiled by those who are trying to overpopularize it. This death will not be a death due to neglect but to an excess of superficial knowledge ... Everyone is talking about development but what is it in reality? One thing is certain: it has no single meaning. Development means something different to each one who speaks." A pertinent question is whether Nigeria has recorded meaningful development over the years for retaining English as the medium of instruction in schools and a compulsory subject in primary and secondary schools; or whether compulsory 
English courses in tertiary institutions (from General Studies Unit) has improved mastery of the subject and developed the society in different ways.

\section{THEORETICAL FRAMEWORK}

This paper argues for the review of the roles and position of indigenous languages in Nigeria, hinging basically on Stewart's theory of language classification cited in Sotiloye (1992) and U. Thant's theory of development (cf. Gheddo 1973:1).

According to Stewart's (ibid.), attributes for classifying languages in a multilingual society include:

$>$ Standardization: This concerns evolving a standard orthography (which is acceptable to all members of the speech community) for the language.

$>$ Autonomy: The members of the speech community must view it as a discrete language from other languages

Distoricity: It should be possible to trace the language to the speakers' ancestral origin.

> Vitality: The language should be able to perform obvious, useful functions among its speakers.

U. Thant's theory of development on the other hand, views development as growth rather than change, which he conceptualizes as diverse modifications in society (new status quo). Change according to this scholar, can be social, economic, qualitative and quantitative. Change in its positive sense, would evolve progress and better living standard in society. Development is the product of proper planning in governance. Within U. Thant's theoretical framework, growth means increase in productivity.

\section{REViving THE STATUS Of Nigerian LANGUAgES}

Nigerian languages have the potentials to develop the country so, they can be taught alongside English in formal instructional setting. Fafunwa (1982, pp. 295-296) declares:

It is our thesis that if the Nigerian child is to be encouraged from the start to develop curiosity, initiative, industry, to manipulative ability, spontaneous flexibility, moral dexterity, mechanical comprehension and the co-ordination of the hand and eye, he should acquire these skills and attitude through his mother-tongue; after all this is the most learning medium. This is where the average European or English child has a decided advantage over his mother tongue; the latter is busy struggling with a foreign language during the greater part of his primary education.

The National Examinations Council (NECO) should be prepared to examine students in most of the indigenous Nigerian languages through PESLIC (Public Examination of Selected Languages of Immediate Community) and UNL (University of Nigerian Languages) proposed in Acheoah (2015a). Indeed, it may not be feasible to examine students in all indigenous languages in Nigeria, linguists and appropriate departments of government can establish rationale for selecting the Nigerian languages that will be examined in Ordinary Level examinations. One of such rationale is linguistic affinity; for example, either Efik or Ibibio may be selected for examination because they share more similar linguistic features (phonological, morphological and semantic properties) as opposed to Efik and Afenmai. Simply put, while proposing the teaching of LIC in primary, secondary and tertiary institutions in the country, Acheoah (2015b) proposes PESLIC as a panacea to the age-long oppression of indigenous languages in Nigeria. This proposal covers all levels of formal education, but with different approaches. In primary schools, National Common Entrance examinations are useful platforms for examining pupils' performance in LIC. In tertiary institutions, the General Studies unit can incorporate LIC as a course alongside courses such as Philosophy and Logic, Use of English, Computer Science, etc. that have long been the courses taught in such units of tertiary education. If $50 \%$ Credit pass in LIC is required by an institution for 
students to graduate, we see no reason why the literacy level in indigenous languages will not increase. Indeed, the PESLIC and UNL projects will increase subjects (or courses) and expand the curriculums at different levels of formal education in Nigeria. It will also create jobs for teachers and foster national integration. PESLIC serves the main purpose of evaluating learners' performance at the end of course work.

The incompetence of teachers has been noted to be a major setback to the teaching and learning of indigenous languages in Nigeria. This is partly accountable for the failure of the National Policy of Education (NPE). The report of the Technical Committee on Production of Teachers for the Three Major Languages remains worrisome:

This committee found that, with the existing secondary schools as of that date, 55,237 teachers were needed in secondary schools, and of this number, only 6,383 were available, made up of Hausa $(1,678)$, Igbo $(18,211)$ and Yoruba $(14,330)$.

Arohunmolase (2006) cites Junaidu and Ihebuzor (1993, p.3) who observe with deep concern, the negative implications of lack of teachers to teach indigenous languages in Nigeria:

"... the problem of the supply of teachers in Nigerian languages represents one of the greatest problems facing the curriculum development efforts in Nigeria. The introduction of Nigerian languages (Hausa, Igbo and Yoruba), as L2 at the JSS level and the Colleges of Education worsened the compounded problem of the supply of trained teachers. It is a matter of great regret that, adequate plans were not made for the supply of teachers before the Federal Government decided to implement the Nigerian languages policy in the Colleges of Education.

Promoting the teaching and learning of only the major languages in Nigeria threatens minority ones and makes them endangered "species". Thus, linguistic nationalism on the part of minority languages culminated into resentments which frustrated NPE policy of teaching and learning the major languages which are said to be the languages of wider communication.

In the Harare Declaration of 1997, African leaders were charged with the responsibility of evolving productive, country-based language policies:

$>$ All African language policies should be those that enhance of attaining the visions of Africa;

$>$ Each country should produce a clear Language Policy Document within which every language spoken in the country can find its place;

$>$ Guidelines for policy formulation should be sanctioned by legislative action;

$>$ Every country's policy framework should be flexible enough to allow each country to use its language sideby-side with other languages while integrating with the wider society, within an empowering language policy that caters for communication at local, regional and international levels;

$>$ A language policy-formulating and monitoring institution/body should be established in each country.

This paper posits that political instability worsens the age-long problem of lack of funds to implementeducational policies in Nigeria, including those policies that concern languages. Adegbija (2004, p.34) submits:

Political instability has been a principal impediment to the implementation of language policy in Nigeria. Previously agreed policies are often abandoned by new regimes and implementation is truncated. There is policy fluctuation, interpretation and misinterpretation and ad hoc and arbitrary policy initiatives.

Adegoju (2009, p.5) notes that "Nigerian government has focused on teaching of science and technology to the neglect of language education." Development processes in Nigeria have long neglected the place of indigenous 
languages as government battles with challenges of modern times: revamping the economy, tackling religious violence, finding solutions to the outbreak of epidemic, quest for scientific and technological breakthrough, and so on. Alien languages have been key linguistic instruments in developing nations including Nigeria. Even UNESCO ranks Africa as "linguistically the least-known continent" in her International Mother Language Day publication. The absence of the role of indigenous languages in nation-building is the reason for the poor ranking of indigenous African languages. Given the prominent position of Nigerian languages in multilingual discourses, it is urgent to relocate the place of such languages in national life. Indeed, Blench (1998, p.1) views Nigeria as "the most complex country in Africa, linguistically, and one of the most complex in the world." Almost 20\% of Africa's more than two thousand languages are spoken in Nigeria. The fate of minority languages therefore calls for worry because they are so many that their continued neglect in nation-building and official contexts spells doom and signals extinction and "linguicide" (language death). Below is the submission of the International Development Research Centre:

Linguists disagree about many aspects of the language situation in Africa, but there is no controversy about the fact that as a continent, Africa presents the most complex linguistic picture in the world. This complexity is due not only to the number of languages spoken by Africans but also to the diversity of the language families and of the functions assigned to the various languages spoken in the same country and, in many cases, by the same individual.

Across the continent, the language situation varies widely; some countries have only one indigenous language, such as Burundi, where everyone speaks a dialect of Kirundi; other countries have hundreds of indigenous languages, such as Nigeria, which has at least 400 . This internal complexity is not just a matter of the number of languages -- it is above all, also a matter of the relative power and status of the languages."

Colonial structures as well as the challenges of globalization deteriorate the role of indigenous languages in Nigeria. Since proficiency in English in Nigeria is not high or impressive, there is need to revisit the plight of indigenous Nigerian languages by assigning functions to them and thus promoting them. Adegbija (2004, p.340) opines that only about 20\% of Nigerians are proficient speakers of English. In their quest for power, dominance and recognition, the few Nigerian elite are the ones who hijack literacy in English. Unfortunately, Bamgbose (1998, p.11) does not think the monopolization of literacy in English by just a few Nigerians can tackle the challenges of nation-building:

The fact is that if development is to be meaningful, there is no way in which it can be carried out in a language which excludes the majority of the people in a society. This, then, is one of the most important justifications for putting greater emphasis on the use and development of a country's indigenous languages."

It is unfortunate that attitudinal factors from various sources have been inimical to the growth of indigenous languages for decades. According to Salawu (2006, p.2) "For any African that is concerned for the soul and survival of his language, there must be a deliberate and sincere effort to learn and teach the language..." In a similar vein, Adegbija (2004, p.54) submits:

Attitudes towards languages are motivated by several factors including their socio-economic value, their statusraising potentials, their perceived instrumental value, their perceive esteem, their perceived functions or roles in the nation, their numerical strength, the perceived political and economic power of its speakers, their use in the official domains, their educational value, etc. Generally, positive attitudes, covert or overt, are developed towards a language that is perceived to have value in all these different areas... Conversely, negative attitudes, overt or covert, develop towards a language in proportion to its lack of function or narrowing or narrowing of its distribution in registers."

Nigerian Languages: The Pedagogical Constraints

According to the National Policy of Education (NPE) (1977, revised 1981, 2000) every Nigerian child should study at least one indigenous language which could be the child's mother tongue or an indigenous language of wider communication in their immediate communities at the pre-primary, primary, junior secondary school 
(JSS) and senior secondary school (SSS) levels of education. However, the three major Nigerian languages: Hausa, Igbo and Yoruba are the ones to be taught as second languages in formal education. Efforts already abound to teach the major languages in Nigeria effectively. However, it is worrisome that such efforts neglected minority languages in the country. Colleges of Education evolved cross-ethnic teaching of major languages in Nigeria, through the Department of Nigerian Languages (Makinde 2005); the National Institute of Nigerian Languages (NINLAN) Aba was established in 1992. However, certain clause of the NPE have been faulted and partly blamed for the failure to revive indigenous languages in formal education. Adegbija $(2004, \mathrm{p}$.20) frowns at the failure of the policy in primary education:

Since most primary schools are private-owned, the Government has only had a very marginal, if any, on language do not use at this level, nor has it been able to enforce the first-language medium policy."

Poor teaching and learning of indigenous languages have been the major cause of student-apathy towards indigenous language subjects in schools. It is not enough to employ teachers to teach languages of immediate communities; such teachers should be competent. It takes competence for teachers to know appropriate test instruments that can facilitate literacy in Nigerian languages. Schools should be provided facilities to cope with the herculean task. For example, there must be standard and adequate language laboratories.

A lot of work has to be done to change the orientation of Nigerians about their Mother Tongues. Indigenous languages are not sub-standard grammar. They are not taboos. The pre-established culture of relegating Nigerian languages to nothingness must be obliterated through proper orientation. Workshops, cultural events, etc. can be organized to polish the image of Nigerian languages both within and outside the country. We do not think it is out of place to establish a University of Nigerian Languages (UNL) in all states of the Federal Republic of Nigeria. Unlike PESLIC which Acheoah (2015b) recommends for selected languages, particularly the minority ones, UNL is proposed for all Nigerian languages. Unlike in the common university system in which students are taught different course that are related to their disciplines in addition to borrowed courses to make them broad-based and versatile, UNL will only offer purely indigenous language courses in addition to a few courses from the General Studies Unit of the University. Therefore, there will be two Faculties (Faculty of Nigerian Languages and Faculty of General Studies). While the Faculty of Nigeria Languages will accommodate all indigenous languages in Nigeria, the Faculty of General Studies will accommodate courses that are borrowed towards broad-based education. There is no need to worry over the fact that this proposal falls short of the benchmark of the National Universities Commission (NUC) for a conventional university. UNL should be considered as "emergent specie", proposed to act as a task-force that will put an end to the endless rhetoric over the revival of indigenous languages in Nigeria. UNL is not to be compared with other universities in Nigeria, although its products should be ranked equally as First Degree graduates and should enjoy same opportunities with university graduates. It takes University of Nigerian Languages to evolve curricula that will enhance the teaching and learning of Nigerian languages. It is worrisome, that instead of promoting the teaching of minority languages in Nigeria, Departments of Linguistics of Nigerian universities concentrate on teaching and learning of French and Asian languages. PESLIC and UNL are critical, novel proposals that will increase the stock of academics in major and minor languages in Nigeria, and this can result in the codification and standardization of those minor Nigerian languages that are fast-becoming endangered species.

The present situation of lack of qualified teachers to teach Nigerian languages (especially the minority ones) portends a major constraint to the success of PESLIC and UNL proposals.

One needs to get these proposals right: they are long-term projects. To cope with the non-availability of qualified personnel to teach Nigerian languages, academics in Departments of Linguistics can begin intensive research towards improving their knowledge of their native languages. Grants and funds should be provided by the government to aid scholarship in this regard. Of course, as language scholars, such academics can easily explore 
residual knowledge of their native languages as well as make productive use of the knowledge they got from the language courses they teach in their respective institutions. The first meaningful step towards making PESLIC and UNL proposals productive is to expand the human facilitators who use the classrooms. School authorities can collaborate with the government in using scholarships to promote literacy in indigenous languages. Acheoah (2015b) recommends that the overall best student in LICx (where the subscript $\mathrm{x}$ is the selected subject e.g. LICEfik) be given awards by public examination bodies in formal award-giving occasions. Healthy competitions promote learning in general and the learning of Nigerian languages is not an exception.

Till date, the government is running a futile mission towards nation-building. This paper contends that Nigeria's development can be achieved via a language therapy within the context of retaining English in formal education, but exploring the country's indigenous languages. For several decades, the government of Nigeria keeps planning towards retaining and improving the status of indigenous languages in the country, by spelling out its functions and premises in formal education and national life. However, no meaningful stride has been registered in post-independence Nigeria as far as developing indigenous languages to effectively contest with English in the country is concerned. If the government does not provide incentives for teaching English towards literacy, Nigeria's overall development will be crippled. It is urgent and necessary to teach the languages of immediate communities effectively in primary, secondary and tertiary institutions in Nigeria.

\section{DISCUSSIONS}

According to Weinrich (1953:57) "The usefulness of a language is the foremost reason for learning it." As noted by May (2001:129), while language is not a determining feature of identity, it is a significant feature in many cases. So long as Nigeria's education system evolves productive ways of teaching the countries indigenous languages, they are candidates for multifaceted national reforms - Wilkins (1975:208) submits: "By studying language in as scientific a manner as possible, we should be able to make change in language teaching a matter of cumulative improvement."

Those who emphasize the divisive potential of indigenous languages as a reason for dislodging them in formal education are pessimists. This paper proposes that language planning decisions can explore the psychological constraints of Nigeria's "multilingual stature" and evolve policies that can promote tolerance. Magnet (1990:56) posits: "Tolerance and generosity towards linguistic minorities promotes good majority-minority relations and leads to a stable polity; attacking a minority's ability to use its own language results in social pathology, uncontrollable political conflict, and widespread difficulties."

Indeed, "there is parallelism between the thoughts of a nation and its language, and language is the medium through which culture is transmitted" - see Schlesinger (1991:12-13) and May (2001:57-58) for instructive positions on this.

It is not surprising if one doubts the feasibility of PESLIC. The position of this paper is that PESLIC is a feasible proposal provided the right measures are put in place to implement it; some states of Nigeria have a dominant language despite the presence of dialects of the language. In this kind of situation, the standard variety (dominant dialect) should be taught in schools towards being examined in public examinations (PESLIC) at the different levels of formal education (Common Entrance in primary schools; WAEC, NECO and JAMB in secondary schools). Within the context of PESLIC, therefore, Standard Igbo will be taught for the Common Entrance Examinations in Igbo-speaking communities, irrespective of the other numerous dialects of Igbo-speaking regions of Nigeria. The same thing will be done for the Ordinary Level Examinations in the communities such that every pupil/ student is made to study the language (dialect) even though it is not his/her language. This practice will create bilinguals and multi-lingual's (polyglots). It will also promote cultural tolerance, linguistic tolerance, peace, national integration and development. Tertiary institutions will take up LIC x (LIC Yoruba, LIC Igbo, LIC Hausa, 
LIC Auchi,) etc. in their General Studies Units. Efforts of Departments of Linguistics in conventional Nigerian universities and Universities of Nigerian Languages across each state capital will be additional strides in the mission to enhance literacy in Nigerian languages. While General Studies Units should concentrate on languages of immediate communities, Departments of Linguistics and Universities of Nigerian Languages will extend their focus on LIC to also teach and promote other Nigerian languages. The University of Nigerian Languages is solely a language-based university, and as such can evolve its own curriculums, undertake its own research, evolve its own policies, and employ its own lecturers and non-teaching staff. This will rescue many Nigerian languages, particularly the minority ones from extinction.

The Credit parameter in secondary schools and the Pass parameter in tertiary institutions will make PESLIC thrive. In a state like Edo where there are different languages (we talk of Yoruba-speaking states but we do not talk of Edo-speaking states because in Edo State there are numerous non-Edo languages) with dialectal variations, more LICs will abound. For example, the Standard variety of Afenmai will be taught and examined in all Afenmai-speaking communities that host primary, secondary and tertiary institutions. Similarly, the Standard variety of Bini will be taught and examined in all Bini-speaking communities that host primary, secondary and tertiary institutions. Teaching and examining just the Standard variety fosters feasibility. Besides, it integrates communities and enhances intra-ethnic cohesion. In addition, it is less capital intensive. In Edo State, communities such as Auchi, Afuze, Agenebode, etc. can teach LIC Auchi (as Standard Afenmai). In cases where the dialectal variation is so much that neighboring linguistic communities become markedly different languages of their super-ordinate, collective name (if for example, all or some Afenmai-speaking communities which are collectively called Afenmai have dialects with so much divergent phonological and morphological features), consensus can be reached as to which of such dialects should operate in PESLIC; this situation can be problematic when speakers do not agree on the Standard variety of the particular language, claiming that they are speakers of a language which is different. Indeed, Acheoah (2015b) proposes Nigerian Languages Festival (NLF) which will:

$>$ Ensure the exhibition of literary works in Nigerian languages;

$>$ Present (performance) songs, poems and drama in Nigerian languages;

$>$ Emphasize inter-ethnic tolerance and national cohesion;

$>$ Educate people via lectures and seminars on language maintenance and promotion strategies (such as using indigenous languages in medical, automobile and telecom products) as well as speaking, reading and writing in Nigerian languages.

Language anchors and conveys cultures of people across races and generations. Thus, language retention is crucial in indigenous knowledge discourses. When language is humiliated individually or collectively and made to die, cultural values and knowledge systems also die with it. According to Kirkness, (1998, p.4) cited in Priscilla Settee (2008) "Language is the principal means whereby culture is accumulated, shared and transmitted from one generation to another. Language expresses the uniqueness of a group's world view." We align with Kirkness (ibid.) who opines that to prevent the disappearance of indigenous knowledge and languages, her communities must establish banks of knowledge to preserve the language and folktales of elders. Contending that storage devices must not necessarily be complex, Kirkness suggests the use of tape recorders for a beginning. There have been several cases of efforts to rescue endangered languages. For example, the Te Kohanga Reo movement based on Maori culture revitalized the culture. Te Kohanga explored the community inclusivity principle (which is immersed in the idea that every community member has skill and purpose) to engage every member of the community in language programming. Supporting the promotion of language, the document Policy Options for Aboriginal Peoples of Canada (1976, p.5) states: "Governments, with international cooperation, should 
provide the necessary financial resources and institutional support to ensure that every indigenous child has the opportunity to achieve both fluency and literacy in his/her own traditional language" (cf. Priscilla, ibid. p.5). The Canadian Indigenous Languages and Literacy Development Institute (CILLDI) was established in 1999 to tackle language development challenges such as shortage of teachers, curriculum developers, researchers, and community linguists who were prepared to work in indigenous language education. The successful strides made by CILLDI is worthy of scholarly attention.

Paul (2009) submits that Nigeria has five hundred and twenty-seven indigenous languages out of which five hundred and fourteen are potent. Fulani, Hausa, Igbo and Yoruba constitute the chunk of the population of the country. The statistics presented on some minority languages in the country is as follows:

$>$ Edo-10\%;

$>$ Kanuri, Ibibio, Nupe and Tiv - (27\%);

$>$ Other minority groups - (7\%).

Yoruba has 19.4, 000, 000 speakers while Igbo is spoken by 18, 000, 000 of the population of the country. The figure of Hausa natives who have native-like control of the language is 25, 000, and 000 (cf. Paul ibid.).

Certain questions are pertinent:

$>$ Where can we place Nigeria which no doubt, has less than $40 \%$ literacy in English?

$>$ How can we conclude that retaining English as the sole medium of instruction in schools has achieved sustainable development in Nigeria?

$>$ Is it not necessary to promote indigenous Nigerian languages to the extent that they can be relevant in literature, entertainment, education, science and technology, advertisement, social mobilization, etc?

$>$ Why do many Nigerian literates mix elements of major or minor languages with English even in officialdom?

$>$ Why does Mother Tongue interference continue to adulterate Nigerian English speakers' utterances?

$>$ Why do Nigerian literary writers rely on local languages in the communication of themes despite that they write such texts in English?

$>$ Why are some radio and television programmers presented and preferred in indigenous Nigerian languages?

Answers to the above questions will remain an interesting discourse. As languages that convey the culture of the Nigerian people, Nigerian indigenous languages can be learnt very easily and become efficient communication instruments. English and its linguistic conventions are alien to Nigerians irrespective of their education or exposure, whereas indigenous Nigerian languages and their conventions are native to Nigerians; contrastive studies show that Nigerian languages share significantly similar phonological, morphological and syntactic features despite the fact that they are discrete languages. For example, grammatical, pragmatic and semantic constraints inform the formation of verbs and adjectives in Afenmai (a minority Nigerian language) and Yoruba (a majority Nigerian language).

The size of speakers of indigenous Nigerian languages is advantageous to the promotion of such languages through formal education. Although literacy (ability to write) in Nigerian languages is not commendable, many Nigerians can speak their indigenous languages up to the extent that their abilities to read and write in such languages can be enhanced. The fact that indigenous Nigerian languages perform vital intra-ethnic functions can be worked upon by language experts and appropriate government agencies.

It is often said that provision of funds and incentives to promote indigenous Nigerian languages is a waste of 
resource. This claim is profoundly unacceptable. Nigeria has enough resources to revive its indigenous languages. A lot of funds are misappropriated by corrupt public officials, yet the government does not probe them. Until leadership is sincere and corruption-free in Nigeria, funds will not be provided for meaningful projects such as the establishment of a University of Nigerian Languages in every state of the Nigerian Federation.

It is often said that indigenous languages breed resentments and have divisive potentials. Those who subscribe to this view are not completely right; some countries make progress out of the peace and tranquility that abound therein. Yet, such countries do not use an alien language as their National Language. Nigeria should key into the benefits of good governance. Once there is good governance, there will be public trust and confidence in the government, and people will confide in the collective goals of the country. This status-quo will make it unnecessary to breed ethnic conflicts. Ethnic conflicts, divisive tendencies and lack of national cohesion are products of ethnic (undemocratic) politics and leadership driven by regional ties and sentiments. We have heard of several cases of people who like a particular language due to linguistic and extra-linguistic factors, yet, hate the native speakers. This is a pointer to the fact that no language is inherently an instrument of rancor and division in Nigeria. Language phenomena are not language-based phenomena. If speakers of language y go about killing native speakers of language $\mathrm{z}$, it is not because of the phonological, morphological or syntactic features of language $y$. It is rather because speakers of language $x$ are transferring aggression due to languagebased phenomena; for example, speakers of language $\mathrm{x}$ may breed hate and strife towards speakers of language $\mathrm{z}$ because an incumbent government is headed by a native speaker of language $\mathrm{z}$, who incidentally, is not fair in the allocation of portfolio and resources of the nation to other regions or ethnic groups.

Nigerian indigenous languages are so communicatively potent that they should not be relegated to the background. Pre-established arguments have been that such languages do not have the extensive vocabulary to cope with the monster, globalization (science and technology). The more Nigerian languages are assigned official functions the more their vocabularies are developed like the vocabulary of English, to cope with modern rhetoric, science and technology. Indeed, the pragma-lexico-semantic credentials of indigenous Nigerian languages are evident in a wide range of discourses, including proverbs. The generation and articulation of Nigerian proverbs are immersed in the existential experiences of different cultures; proverbial constructs are informed by norms, values and social phenomena and figurative devices (particularly metaphor) that concern Nigerians.

Teaching tropes in indigenous languages facilitate the understanding of tropes in English. This will go a long way to help secondary school students who offer English literature as a career requirement. In Nigerian languages, extended language (tropes) is used to make discourse vehement; symbolism and metaphor are dominant in discourses expressed in Nigerian languages. A wide range of strategies of rhetoric are exhibited through Nigerian languages, and this accentuates their communicative potentials. For example, analogies are often used to extend discourse, while metaphors concretize messages. In Yekhee/Afenmai (a minority Nigerian language) for example, a noun can be used to refer to more than one thing, in which case the referent is speakerbased. For instance, Otoo means "ground" or "floor". Similarly, Ade ke means "fool" or "foolishness". Also, the noun èlamhi (meat) is used both normatively to mean "meat that can be eaten" and pragmatically to mean "a foolish person"). Yekhee words cut across word-class: nouns, pronouns, adjectives, verbs, etc. The words are skillfully "deposited" in multi-facetted discourse situations as strategies of rhetoric. The speaker ensures that the meanings (semantic components) are not always denotative. Mutual contextual beliefs among interlocutors facilitate pragmatic shift from conventional meanings of words unto context-driven meanings that register speakers' idiosyncratic competence. In many Nigerian languages, meaning can be defined in terms of use (the meaning of a sentence is determined by the set of acts it performs in communicative situations) and context (contextual variables which may be social, psychological, pragmatic, or linguistic). Therefore, if Yekhee, being a Language of Immediate Community is taught alongside English, there will be positive transfer rather than 
interference on the part of Yekhee learners of English. PESLIC and UNL will enable Nigerian learners of English to progress from learning English towards literacy to learning it towards proficiency.

The practices in formal education in Nigeria reveal that indigenous languages in the country are downtrodden; are not to be spoken in primary or secondary school environments. The inscription on doorposts and walls of schools is: "Speak English always". In fact, school prefects are instructed to locate culprits (those who speak vernaculars) for punishment. It is unfortunate that parents patronize English-speaking schools and pay huge tuition fees for their children. A yardstick for measuring standard in primary and secondary schools in contemporary Nigeria is English-speaking. Ayodabo and Acheoah (2013) note that as a result of the importance placed on the speaking of English in Nigerian schools, Ghanaian teachers are more remunerated than their Nigerian counterparts who teach in such schools. This is the situation, even in cases where such Nigerian teachers have same or higher academic qualifications than their Ghanaian counterparts. In tertiary institutions in Nigeria, English is the language of instruction and interaction. However, the people of Nigeria mostly communicate in their Mother Tongues outside officialdom. So long as the cognitive maturity (reasoning and understanding) of Nigerians is more reflected in their Mother Tongues, indigenous languages should be given adequate attention in formal education.

Given the illiteracy rate in Nigeria many Nigerians cannot cope with the challenges of modern technology. For example, they cannot operate ATM machines because such machines are configured in English. The resultant situation is that they expose the pin numbers of their ATM cards to those who assist them in performing their transactions. Apart from the risks involved, it wastes the precious time of others on the queue. One may not need to wonder why those who cannot operate ATM technology still go ahead to possess same; banks insist that it should be so. Scholars have expressed the need for the development of ATM interface technologies which are expressed in indigenous languages. Teaching and learning Language of Immediate Community can promote literacy level in Nigerian languages so much that even students who are not natives of a particular ethnic group will be exposed to reading and writing in the language of such an ethnic group. Through this, bilinguals and multi-lingual's (polyglots) will become common in Nigeria. Learners of languages that are not their native languages can end up performing better in such languages. In the long run, tribal sentiments, resentments and divisive tendencies will pave way for national cohesion and sustainable development.

One of the reasons for poor literacy in Nigerian languages is that formal education in the country does not provide a fertile ground for indigenous languages to thrive. It is deceptive for those who speak Mother Tongues to think they are literates in such Mother tongues when obviously, they cannot write in same. The age-long tenacious cleavage which Nigerian languages have in oral tradition is believed to be the reason for low literacy in Mother Tongues. Since indigenous languages are strongly rooted in society, they have more prospects than English if only adequate and appropriate steps are taken by government, schools and students to revive them. Nigeria should begin to learn from Japan and China; these two countries have dazzled the world in terms of reaching the crescendo of technological breakthrough without an alien National Language. In Nigeria, the project of a Mother Tongue as a National Language has remained a matter of rhetoric and intellectual tournament for decades. So long as success is the aggregate of inputs, Nigeria can revive the roles and status of indigenous language with sincerity and goal-driven approach. It is slavish that Nigerians continue to promote English in their respective endeavors: many celebrated Nigerian literary writers mainly write their works in English, in which case they solely propagate Western Language and culture. For example, characterization in plays and novels written by Nigerian scholars is often used to establish class dichotomy; poor, miserable, uneducated characters are made to speak vernacular or Nigerian Pidgin (NP) in the name of local color. This is arrant nonsense! The translation of the Holy Bible by Samuel Ajayi Crowther remains epoch-making. Although Chinua Achebe's Things Fall Apart was translated into 54 languages across the world, one does not know of any Nigerian language that the novel was translated into. Why can't Nigerian writers become literates in Mother Tongues, thereby exhibiting their 
aesthetic prowess and literary ingenuity in indigenous languages?

Realizing the importance of Mass Literacy, the government of Nigeria formulated Adult Education policies and evolved its attendant programmes. They also embarked on education schemes to rescue the less-developed regions of the country. However, the government bodies saddled with the responsibility of implementing Mass Literacy programmes failed to realize that illiteracy in English which is solely the medium of instruction in Mass Literacy in Nigeria, would be a setback to the achievement of set-goals.

\section{CONCLUSION}

Indeed, Nigerian languages are autonomous, have historical roots and play vital socio-cultural roles in the Nigerian speech community. However, their absence in formal education should be properly re-examined. This submission is crucial, given the fact that such languages are vital resources for national development; Acheoah (2015a) is therefore a protest-discourse which contends that UNLs is the panacea to the age-long, traditional neglect of Nigerian languages in important spheres of nationhood. According to Bloomaert (2010:28) "Sociolinguistics is the study of language as a complex of resources." Unfortunately, the literature indicates that Nigerian languages are not given attention in formal education, not to talk of exploring their latent potentials in national development. Even the major ones are not effectively studied in schools. This explains why many students fail SSCE examinations in Yoruba, Hausa and Igbo. This ugly situation should be revisited. Failure rate in indigenous languages is neither arbitrary nor incidental - Schmidt (1995:20) notes: "What learners notice in input is what becomes intake for learning."

The implications of repositioning indigenous languages in Nigeria are numerous: it leads to standardization, codification, national mobilization, expansion of the functions of Nigerian languages, national cohesion, increase in political participation, expansion of the curriculums, job creation, extensive research, significant shift from oral competence in language to literacy in reading and writing as well as expansion of the literary potentials of indigenous languages.

\section{REFERENCES}

1. Acheoah, J. E. (2014). “Ordinary Level English in Nigeria: On Assessment and Failure.” International Journal of English Language, Literature and Translation Studies, Vol. 1. Issue 2:1-5.

2. (2015a). "University of Nigerian Languages (UNLs) Prospects and Initial Hurdles." International Journal of Linguistics, Volume-1, Issue-1:1-6.

3. (2015b). "Sustainable Development in Nigeria: The Candidature of Language of the Immediate Community", a paper presented at the International Conference on the Humanities and the Indigenous Knowledge System (IKS) in Africa and Africa's Diasporas, organized by Faculty of Arts, Lagos State University and African Studies Institute, Georgia, Athens, USA, held at the Lagos State University, Lagos, Nigeria between $20^{\text {th }}$ and $23^{\text {rd }}$ July, 2015.

4. Adegbija, E. F. (2004). "Language Policy and Planning in Nigeria." Current Issues in Language Planning. 5(3):1-66.

5. Adeyemi, Adegoju. (2009). "Language Teaching, Learning and Utility: A Triadic Paradigm for Revitalising Indigenous Nigerian Languages." International Journal of Language Society Culture, Issue 27.

6. Arohunmolase, O. (2006). "Globalization and the Problems and Prospects of Teaching and Learning of Yoruba as a Second Language (L2) in Colleges of Education in Nigeria." In Arasanyi, O. F. and M. A. Pemberton (Eds.) (2006). Selected Proceedings of the $36^{\text {th }}$ Annual Conference on African Linguistics, pp. 129-132.

7. Ayodabo, J. O. and Acheoah, J. E. (2013). “Nigerian English in a Decolonized State: Prospects and Constraints." International Journal of Arts and Humanities, Volume 2, Issue 2:48 - 52. 
8. Ayodabo, J. O. (2014). Linguistic and Sociolinguistic Situation in Nigeria. Ilorin: Haytee Press.

9. Bamgbose, A. (1998). "Language as a Resource: An African Perspective." In Ambrose M., J. Read and V. Webb (Compilers) Workshop Papers: The Role of the African Languages in Democratic South Africa. Pretoria: University of Pretoria, CentREPoL, pp.1-14.

10. Blench, R. (1998). "The Status of the Languages of Central Nigeria." Brenzinger, M. (Ed.) Endangered Languages in Africa, Koln: Koppe Verlag pp. 1-13.

11. Bloommaert, J. (2010). The Sociolinguistics of Globalization. Cambridge: Cambridge University Press.

12. Emenajo, N. (2010). "Functional Illiteracy: The Bane of National Development." Ndimele (Ed.) English Studies and National Development in Nigeria. ELTAN, pp.1-32.

13. Fafunwa, A. B. (1982). "Yoruba in Education-Integrated Primary School Curriculum Scheme in Nigeria: A Six-year Project." Afolayan, A. (E.d.), Yoruba Language and Literature, Ife and University Press Limited, pp. 291-299.

14. Gheddo, Piero. (1973). Why is the Third World Poor? (Translated by Kathryn Sullivan). New York, Maryknoll: Orbis Books. Harare Diclaration.Web.10 ${ }^{\text {th }}$ May, 2008. http:www.bisharat.net/Documents/ Harare97 Declaration.htm. p.2, 1997.

15. Magnet, J. (1990). "Canadian Perspectives on Official English.” In K. Adams \& D. Brink (Eds.) Perspectives on Official English (pp. 53-61). New York: Mouton de Gruyter.

16. Makinde, S. O. (2005). "Yoruba Language Acculturation Program for Teacher Training in Nigeria." Electronic Magazine of Multicultural Education, 7(1), 2005.

17. May, S. (2001). Language and Minority Rights: Ethnicity, Nationalism and the Politics of Language. Harlow: Pearson Education Limited.

18. Paul, M. (Ed). (2012). "Ethnologue: Languages of the World." Web. 16 $6^{\text {th }}$ Edition, 2009. Dallas,Tex:SIL URL:http//www.ethnologue.com/show language .asp? code=pcm.

19. Salawu, A. (2006). "Indigenous Language Media: A Veritable Tool for African Language Learning." Journal of Multicultural Discourses, 1(1) 86-95.

20. Schlesinger, I. M. (1991). The Wax and Wane or Whorfian Views. In: R. L. Cooper and B. Spolsky (Eds.) The Influence of Language on Culture and Thoughts: Essays in Honor of Joshua A. Fishman's Sixty-Fifth Birthday. Berlin and New York: Mouton de Gruyter, pp. 7-45.

21. Schmidt, R. W. (1995). "Conciousness and Foreign Language Learning: A Tutorial on the Role of Attention and Awareness in Learning." In R. W. Schmidt (Ed.), Attention and Awareness in Foreign Language Learning. (Tech. Rep. No. 9, pp. 1-63). University of Hawai' I at Manoa, Second Language Teaching and Curriculum Centre.

22. Settee, Priscilla. (2008). “Native Language Supporting Indigenous Knowledge." International Expert Group Meeting on Indigenous Languages. New York.

23. Sotiloye, Bosede. (1992). "Sociolinguistics." Yusuf O. ed. Introduction to Linguistics. Ilorin: Department of Linguistics and Nigerian Languages, University of Ilorin, p.144.

24. The International Development Research Centre, "Chapter 1. Policy Contexts in Africa: Issues, Problems and Constraints". Web. 14 ${ }^{\text {th }}$ June, 2008. http://www:idrc.ca/en/ev-31086-201-1-D0-Topic.html, p.1

25. The Asmara Declaration on African Languages and Literatures, [www document] URL: http://www. queensu.ca/snid/ asmara.htm p.1

26. UNESCO Press Release on the International Mother Day,"Linguistic Diversity:3,000 Languages in Danger, [ 
American Research Journal of English and Literature(ARJEL)

www document] URL: Http://www.unesco.org/education/imld- 2002/press.shtml p.2

27. Weinrich, U. (1953). Languages in Contact. New York.

28. Wilkins, D. A. (1975). Linguistics in Language Teaching. London: Edward Arnold.

Citation: Acheoah, John Emike, Department of European Languages, Federal University, Birnin-Kebbi, Nigeria. Indigenous Knowledge System (IKS) and Sustainable Development in Nigeria: The Candidature of Language of Immediate Community (LIC) ARJEL Volume 2016; pp:1-13

Copyright (C) 2016 Acheoah, John Emike This is an open access article distributed under the Creative Commons Attribution License, which permits unrestricted use, distribution, and reproduction in any medium, provided the original work is properly cited. 